\title{
Development of Physics Learning Media Based on Website with Problem-Based Learning Model
}

\author{
Teguh Febri Sudarma ${ }^{1 *}$, Ratna Tanjung ${ }^{1}$, Purwanto ${ }^{1}$ \\ \{* teguhfebri@unimed.ac.id \} \\ Physics Education Department, Faculty of Math and Science, Universitas Negeri Medan, Indonesia ${ }^{1}$
}

\begin{abstract}
This study aims to develop a web-based physics learning media with the Problem Based Learning (PBL) model in the Basic Physics course I and to find out how effective the web-based learning media are with the Problem Based Learning model in Basic Physics I. This research is a Research and Development with a development model from Borg \& Gall. The results of the material validator were $80.5 \%$ of the content quality, aspects of material language usage $83 \%$, the visual appearance of material $85 \%$, Sound Aspects of the Material 83\%, Ease of use of material 90\%, 84\% Problem-Based Learning Model with eligibility criteria $84,3 \%$. The assessment category is "very feasible", this means that website-based physics learning media with the Problem Based Learning model are by the learning material and are suitable for use in learning. The results of the media validator are $86 \%$ media effectiveness and efficiency, reliable from the media $83 \%$, Media content is $87 \%$, Ease of media use is $85 \%$, Accuracy of $85 \%$ authoring tools, Media compatibility $83 \%$, Media Integration $85 \%$, Media documentation $82 \%$, Media consistency $80 \%$, with media eligibility criteria of $84 \%$. The assessment category is "very feasible", product trials include small groups and field trials on Problem Bases Learning-based website learning media obtained that the learning media is feasible to use with details of the results of small group trials conducted obtained at $86 \%$. Based on the results of field trials conducted obtained by $89 \%$. It means that the website-based physics learning media with the Problem Based Learning model is by the learning media and is suitable for use in learning.
\end{abstract}

Keywords: Problem-based learning, media feasibility, website learning media

\section{Introduction}

The rapidly developing information technology is currently not separated from the size of internet users. According to survey results carried out by the Indonesian Internet Service Providers Association (APJII), the number of internet users in Indonesia reached 143.26 million from the total population of 262 million. This figure increased by $7.96 \%$ from 2016 which was recorded at 132.7 million people. Internet technology enables learning media that can interact with two or more directions online. Based on the above data the use of the internet can be used to develop learning activities in schools, universities or tutoring because of the use of interactive internet learning media that can reach various countries [1]

Progress in the field of information and communication technology (ICT) enables the development of online learning resources. Mills [2]states that the Source of Online Learning enables the learning process to be able to achieve the form of "complex skills" needed in the global era while at the same time enabling the Student-centered learning. Fullick [3] mentions 
"in student-centred classroom the goal of education is independent creation, autonomous learners who assume the responsibility for their learning".

Integrating information technology into the learning process can improve literacy, building on the characteristics of a knowledge-based society in students, while increasing the effectiveness and efficiency of the learning process itself [4]. Web-based learning media that is supported by a database is one alternative that can be used as an effective alternative method. This web-based learning media consists of learning material, audio, and learning evaluation [5]. Web-based learning media or e-learning is now becoming popular because of its flexibility and effectiveness is a way of delivering learning material through the internet that can be accessed anytime and from anywhere [6]. Students can use the website as a means to get physics material whenever and wherever students need or as a medium of discussion or practice. In the development of e-learning websites/systems it is mostly used by educational institutions where, "Overseas like in the US, e-learning has been used in almost $90 \%$ of universities that have more than 10,000 students" [7].

There are three types of internet learning systems that are used as references in the development of learning media using the internet; the first web course is the use of the internet in the learning process where all teaching materials, discussions, consultations, assignments, exercises and examinations are carried out using the internet. The second web-centric course is the use of the internet in the learning process in which all activities are carried out with internet media but at a particular time are held face-to-face to discuss between lecturers and students. The third web-enhanced course, known as the web lite course, is the teaching and learning process that prioritises direct face-to-face classes, the function of the internet here is to provide enrichment and a place of communication between lecturers and students or between students and students with other learning resources [8]. Therefore, the lecturers are required to master literacy techniques, create teaching materials, and learning media through the web to generate interest in student learning. Mastery of concepts and problem-solving abilities in physics learning as one aspect in evaluating the achievement of student learning outcomes in order to achieve effectively and quality learning can be used internet / websitebased learning media. Through website-based learning media, students can learn independently and actively by accessing websites. The use of the website is expected to facilitate students in understanding the physics material that is abstract; students can repeat the lesson by accessing the website and students can also practice the skills in answering questions by completing the practice questions on the website prepared by the lecturer.

Problem-Based Learning Model is a model of learning that requires students to develop skills of thinking, problem-solving and intellectual skills, fostering skills inability to cooperate, and developing social attitudes. Learning with the Problem Based Learning model is expected to provide opportunities for students (students) to be able to improve scientific work skills.

Based on the results of observations so far, the learning process in basic physics courses I, some lecturers still use print media or printed books in conducting the learning process, so that lecturers do not maximise time in delivering learning material. In order to improve the quality standards of graduates and improve curriculum in physics majors regularly and periodically evaluate and develop programs such as the implementation of lectures, results achieved and material presented whether it is still efficient, effective and relevant to market demands.

The teaching and learning process in the physics department needs to take advantage of information technology advances by presenting website-based learning media easily accessible from the hands. Especially for Physics education practitioners. Physics as one of the 
subjects that most people find demanding needs to be presented creatively and follows a lifestyle (lifestyle).

Therefore, it is crucial to design a website-based physical learning media using the Problem Based Learning model, especially in basic physics courses I, so that the learning process becomes effective and efficient by market demands and the creation of competent graduates.

The development of website-based learning media has been done a lot like what has been done, among others by Arsi in high school on dynamic electricity subject matter, obtained results of $91.35 \%$ with good categories and the resulting media are feasible [9]. Development of web-based physics learning media to improve Adherence Quotient is deemed feasible [10]. The development of web-based E-learning conducted by Iful in 2015 with a 4D model obtained by web-based media is feasible [11]. The development of website-based learning media with the Discovery Learning Guide approach conducted by Sherly also states that it is feasible to use [12]. Development of a web-based Blended Learning Media enhanced Course, active can foster an interest in learning physics by $65 \%$ [13].

The development of web-based learning media for natural science subjects for class VII students conducted by Januarman dan Ghufron using Wordpress CMS is feasible as a learning media based on media validation and material experts [6]. Development of web-based learning media to measure results student learning on primary network computer subjects computer and network engineering expertise programs conducted by Heni and Hary using the ADDIE development model obtained an average test of $88.55 \%$ stating that this media is feasible [14]. The development of website-based learning for generation $\mathrm{Z}$ conducted by Bambang, Dewiyani and Pantjawati using Google Apps For Education (GAFe) states that it can improve learning outcomes and be feasible to use [15]. The development of web-based media and elearning in physics material in senior high schools conducted by Saraswati produces webbased learning media in physics subjects in high schools is feasible [16]. The development of homework-oriented webs on physics subjects conducted by Demirci shows that homework performance increases significantly [17]. Research conducted by Ridha and Nurman in the use of blogs in the geographic information system course stated that there was an increase in student learning outcomes when using blogs as a learning medium [18].

The development of problem-based technology-based learning media in general only emphasises technology and ignores Problem-based learning research itself, especially the learning mechanism related to problem-solving [19]. The use of problem-based learning models based on websites is more effective than Content-based learning, where students have a more positive response to increased knowledge by using website-based problem-based learning models [20].

\section{Methodology}

The research method used in this study is Research and Development/Research and Development (R \& D). The R \& D model that will be used in this study refers to a design developed by Borg \& Gall [21], 1) Research and information collecting, 2) Planning, 3) Develop preliminary form of product, 4) Preliminary field testing, 5) Main product revision, 6) Main field testing, 7) Operational product revision, 8) Operational field testing, 9) Final product revision, 10) Dissemination and implementation, and limited to part seven of ten in 
this study the part is due to the seven steps that have been able to answer the research problem. The procedure carried out in this study is as shown figure 1 .

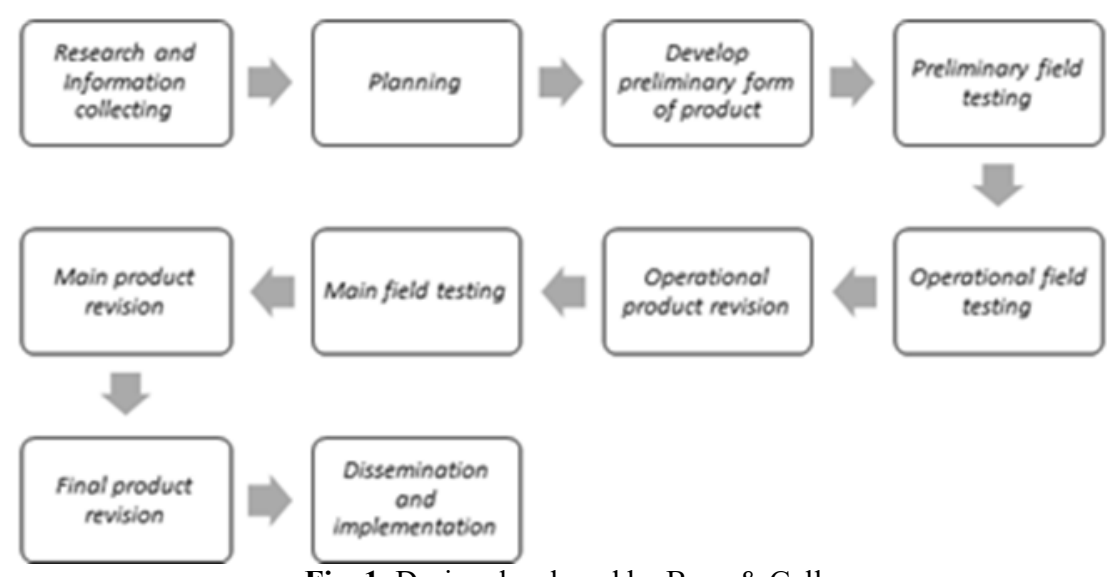

Fig. 1. Design developed by Borg \& Gall

Media validation is a process to assess whether web product design with problem-based learning (PBL) model has been categorized as an effective and efficient website in increasing students' interest in learning. In the validation stage, the initial product design was consulted to the Expert team consisting of material experts and media experts.

After material experts and media experts validate product design, we can find out the weaknesses or shortcomings of website-based learning media with the problem-based learning model. These weaknesses are improved to produce better and more effective products. Product testing is an important part of development research carried out after the product design is complete. For product testing carried out using small group tests and field trials

After the product is validated by material and media experts and has been tested in small groups and field trials, the weaknesses of the product can be identified. The weakness is then corrected to produce a better product.

\section{Result and Discussion}

This research was conducted at the Physics Department of Medan State University. The distribution of questionnaires and small group trials were carried out to students of the 2017 Physics Education Study Program, while the large group trials were conducted for students of the 2018 Physics Education Study Program.

\subsection{Research and Information Collecting}

The results of the observation of the need for media from this study is the need for interactive learning media that can be used anywhere and supported by a problem-based learning model. It is also expected that with this learning media the learning process will be more effective and can improve learning outcomes. 


\subsection{Planning}

After the next observation process is to collect the required data including the needs of the lecturer and students on the learning media needed. Based on the results of the analysis obtained that lecturers need interactive website-based physics learning media that can be combined with the Problem Based Learning model in basic Physics courses.

\subsection{Develop a Preliminary Form of Product}

Some things are done in product design Media-based learning of Physics Website with the Model of Problem Based Learning. The design of this media product is to find a suitable idea for PBL, determine the material to be displayed, Determine the web system that will be created including material (teaching materials), images, videos and animations, and determine the hosting and the suitable domain. This follows the display of Website Design.

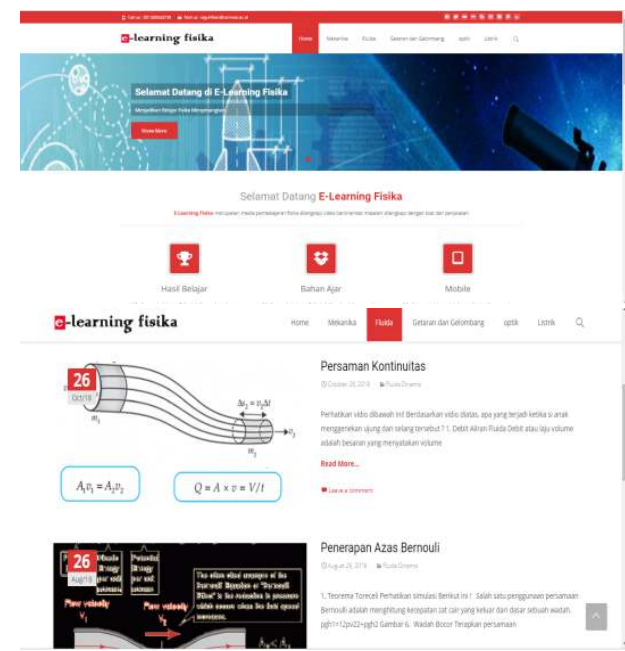

Fig. 2. Display of the e-learning website

\subsection{Preliminary Field Testing}

After the product has been designed, the next step is to validate the feasibility of the media. The validation of media feasibility was carried out by six experts consisting of 3 material experts and three media experts. The criteria in determining the validator are experienced in their field and have a minimum of S2 education. The results of the validation of material experts and media experts are as follows:

\subsubsection{Material Validation}

The results of the material validation of the Website-Based Learning Media with the Problem Based Learning Model in the Basic Physics course as shown in the table below.

\begin{tabular}{clc} 
& \multicolumn{2}{c}{ Table 1. Results of Material Expert Validation } \\
\hline No & \multicolumn{1}{c}{ Assessment Aspect } & $\begin{array}{c}\text { Feasibility } \\
\text { Percentage }\end{array}$ \\
\hline 1 & Quality of Material Content & $80,5 \%$ \\
2 & Language aspects & $83 \%$ \\
3 & Visual Display & $85 \%$ \\
4 & Sound Aspects of theMaterial & $83 \%$ \\
\hline
\end{tabular}




\begin{tabular}{clc}
\hline No & \multicolumn{1}{c}{ Assessment Aspect } & $\begin{array}{c}\text { Feasibility } \\
\text { Percentage }\end{array}$ \\
\hline 5 & User Ease & $90 \%$ \\
6 & $\begin{array}{l}\text { Model of Problem Based } \\
\text { Learning }\end{array}$ & $84 \%$ \\
\multicolumn{2}{c}{ Average } & $84 \%$ \\
\hline
\end{tabular}

\subsubsection{Validation of Media Experts}

The results of the media expert validation from the Website-Based Physics Learning Media with Problem-Based Learning Model in the basic physics subject can be seen as in the table below.

Table 2. Results of media expert validation

\begin{tabular}{llc}
\hline No & \multicolumn{1}{c}{ Assessment Aspect } & $\begin{array}{c}\text { Feasibility } \\
\text { Percentage }\end{array}$ \\
\hline 1 & Effectiveness and Efficiency & $86 \%$ \\
2 & Reliable & $83 \%$ \\
3 & Maintainable & $87 \%$ \\
4 & User Ease & $85 \%$ \\
5 & The accuracy of Type authoring tools & $85 \%$ \\
6 & Compatibility & $83 \%$ \\
7 & Integrated Media & $85 \%$ \\
8 & Documentation & $82 \%$ \\
9 & Consistent & $80 \%$ \\
\hline \multicolumn{2}{c}{ Average } \\
\hline \multicolumn{2}{c}{}
\end{tabular}

\subsubsection{Main Product Revision}

After a website-based physics learning media with a problem-based learning model is validated, the next step is to make improvements. The results of improvements to the design of instructional media are explained as follows:

a. Results of Material Material Validation Improvement

The results of the improvement of material expert validation on the development of website-based physics learning media with the Problem Based Learning Model in basic physics courses are as follows:

Table 3. Material expert criticism and advice

\begin{tabular}{cll}
\hline No & \multicolumn{1}{c}{ Criticism and suggestions } & \multicolumn{1}{c}{ Ccorrections } \\
\hline 1 & $\begin{array}{l}\text { More physics simulations need to be } \\
\text { added }\end{array}$ & $\begin{array}{l}\text { Physics simulation has been } \\
\text { added }\end{array}$ \\
2 & Need to add an explanation using images & $\begin{array}{l}\text { An explanation has been added } \\
\text { using images }\end{array}$ \\
\hline
\end{tabular}

b. Results of Improving Media Expert Validation

The results of the improvement of media expert validation on the development of website-based physics learning media with the Problem Based Learning model in basic Physics courses are as follows:

Table 4. Media expert criticism and advice

\begin{tabular}{cll}
\hline No & \multicolumn{1}{c}{ Criticism and suggestions } & \multicolumn{1}{c}{ Ccorrections } \\
\hline 1 & $\begin{array}{l}\text { The use of colour must be more } \\
\text { varied }\end{array}$ & $\begin{array}{l}\text { Already done repairs by the } \\
\text { advice of the validator }\end{array}$ \\
2 & $\begin{array}{l}\text { Physics simulations need to be } \\
\text { improved again }\end{array}$ & $\begin{array}{l}\text { Already done repairs by the } \\
\text { advice of the validator }\end{array}$ \\
\hline
\end{tabular}




\begin{tabular}{cll}
\hline No & \multicolumn{1}{c}{ Criticism and suggestions } & \multicolumn{1}{c}{ Ccorrections } \\
\hline 3 & $\begin{array}{l}\text { The simulation must be more } \\
\text { interactive } \\
\text { Add videos }\end{array}$ & $\begin{array}{l}\text { Already done repairs by the } \\
\text { advice of the validator } \\
\text { Already done repairs by the } \\
\text { advice of the validator }\end{array}$ \\
\hline
\end{tabular}

\subsubsection{Main Field Testing}

In this small group trial carried out by ten students who had attended basic physics courses at Medan State University can look like the table below.

Table 5. Small Group Trial Results

\begin{tabular}{clc}
\hline \multicolumn{2}{c}{ Table 5. Small Group Trial Results } \\
\hline No & \multicolumn{1}{c}{ Assessment Aspect } & $\begin{array}{c}\text { Feasibility } \\
\text { Percentage }\end{array}$ \\
\hline 1 & Increase student knowledge & $86 \%$ \\
2 & Ease of use & $78 \%$ \\
3 & Increase student interest & $86 \%$ \\
4 & The ease of starting the program & $84 \%$ \\
5 & Clarity of instructions for use & $86 \%$ \\
6 & Use of language & $90 \%$ \\
7 & Usage of letters & $86 \%$ \\
8 & Use of colour & $84 \%$ \\
9 & Use of images & $88 \%$ \\
10 & Use of illustrations & $88 \%$ \\
11 & Use of sound & $86 \%$ \\
\hline \multicolumn{2}{c}{ Average } \\
\hline
\end{tabular}

Based on the results of the small group experiment, the effects of Problem Bases Learning were obtained by a percentage of $83 \%$, the assessment of learning media gained an average percentage of $87 \%$, and a small group assessment of the technical design of website-based learning media was $86 \%$. From this, it can be concluded that the average percentage assessment of small group trials is $86 \%$. Field trials were carried out for 2018 class B physics class students who followed physics courses as seen in the table below.

Table 6. Field Trial Results

\begin{tabular}{clc}
\multicolumn{3}{c}{ Table 6. Field Trial Results } \\
\hline \multirow{2}{*}{ No } & \multicolumn{1}{c}{ Assessment Aspect } & $\begin{array}{c}\text { Feasibility } \\
\text { Percentage }\end{array}$ \\
\hline 1 & Increase student knowledge & $95,00 \%$ \\
2 & Ease of use & $83,33 \%$ \\
3 & Increase student interest & $95,00 \%$ \\
4 & The ease of starting the program & $83,33 \%$ \\
5 & Clarity of instructions for use & $88,33 \%$ \\
6 & Use of language & $90,83 \%$ \\
7 & Usage of letters & $91,67 \%$ \\
8 & Use of color & $90,83 \%$ \\
9 & Use of images & $89,17 \%$ \\
10 & Use of illustrations & $89,17 \%$ \\
11 & Use of sound & $80,83 \%$ \\
\hline
\end{tabular}

Based on the field experiments conducted, the effects of Problem Bases Learning were obtained by a percentage of $91.11 \%$, the assessment of learning media gained an average percentage of $87.50 \%$, and a small group assessment of the technical design of website-based learning media was $88 \%$. From this, it can be concluded that the average percentage assessment of small group trials was obtained at $89 \%$. 


\section{Conclusion}

The initial planning of designing a website-based physics learning media with a problembased learning model is to create learning media that can make the learning process more effective and efficient. In the process of designing learning media, the initial stage is to find ideas, analyse the material displayed, determine the web system that will be created. At this stage, the web system used by using WordPress is added to moodle in the exam process. Use of the domain used is e-leaning.teguhfebri.com with hosting a capacity of $10 \mathrm{~GB}$. These website-based physics learning media is expected to help the teaching and learning process in basic physics courses.

Based on the assessment and analysis of material experts, it was declared valid. Please note that in the expert validation stage the material has been carried out several stages of improvement so that the average percentage is very satisfying.

The results of the material validator were $80.5 \%$ of the content quality, aspects of material language usage $83 \%$, the visual appearance of material $85 \%$, Sound Aspects of the Material $83 \%$, Ease of use of material $90 \%, 84 \%$ Problem-Based Learning Model with eligibility criteria $84,3 \%$. The assessment category is "very decent", this means that the website-based physics learning media with the Problem Based Learning model is by the learning material and are suitable for use in learning.

Based on the assessment and analysis of media experts, it is declared valid. Please note that in the media expert test phase several stages of improvement have been carried out so that the average percentage score is very satisfying. The results of the media validator are $86 \%$ media effectiveness and efficiency, $83 \%$ of media reliability, $87 \%$ media, $85 \%$ ease of use, $85 \%$ accuracy of authoring tools, $83 \%$ media compatibility, $85 \%$ media integration, media documentation $82 \%$, Media Consistency is $80 \%$, with criteria for media eligibility of $84 \%$. The assessment category is "very feasible", this means that the website-based physics learning media with the Problem Based Learning model is compatible with the learning media and are suitable for use in learning.

Product trials include small groups and field trials on Problem Bases Learning-based website learning media obtained that the learning media is feasible to use with the details of the results of small group trials conducted obtained by the effects of Problem-Based Learning in a percentage of $83 \%$, assessment of learning media gained the average percentage is $87 \%$, and the small group assessment of the technical design of website-based learning media is $86 \%$. From here it can be concluded that the average percentage of small group trial evaluations was $86 \%$. Based on the field experiments conducted, the effects of Problem Bases Learning were obtained by a percentage of $91.11 \%$, the assessment of learning media gained an average percentage of $87.50 \%$, and a small group assessment of the technical design of website-based learning media was $88 \%$. From this, it can be concluded that the average percentage assessment of small group trials was obtained at $89 \%$.

\section{References}

[1] APJII, "Penetrasi \& Perilaku Pengguna Internet Indonesia," 2017.

[2] S. C. Mills, Using the internet for active teaching and learning. Pearson/Merrill/Prentice Hall, 2006.

[3] P. Fullick, Teaching Secondary Science With ICT. New York: McGraw-Hill Education, 2004.

[4] P. Yuliatmojo, "Mempersiapkan Guru Pada Strategi Pembelajaran Berbasis Teknologi Informasi Dan Komunikasi," Pros. APTEKINDO, vol. 6, no. 1, 2012. 
[5] A. Pratomo, "PERANCANGAN MEDIA BELAJAR INTERAKTIF BERBASIS WEB MENGGUNAKAN METODE PROMETHEE," J. Ilm. Teknol. Inf. Asia, vol. 7, no. 2, pp. 50 59, 2013.

[6] E. Januarisman and A. Ghufron, "PENGEMBANGAN MEDIA PEMBELAJARAN BERBASIS WEB MATA PELAJARAN ILMU PENGETAHUAN ALAM UNTUK SISWA KELAS VII," J. Inov. Teknol. Pendidik., vol. 3, no. 2, pp. 166-182, 2016.

[7] B. Basori, "PEMANFAATAN SOCIAL LEARNING NETWORK $\gg$ EDMODO DALAM MEMBANTU PERKULIAHAN TEORI BODI OTOMOTIF DI PRODI PTM JPTK FKIP UNS," JIPTEK J. Ilm. Pendidik. Tek. dan Kejuru., vol. 6, no. 2, 2013.

[8] A. H. Suyanto, "Step by step web design theory and practices," Yogyakarta Andi, 2009.

[9] F. Arsi and K. V. Febrianti, "Pengembangan Media Pembelajaran Fisika Berbasis Web untuk SMA Kelas X pada Pokok Bahasan Listrik Dinamis," in PROSIDING: Seminar Nasional Fisika dan Pendidikan Fisika, 2014, vol. 5, no. 1.

[10] A. C. Putri, "PENGEMBANGAN MEDIA PEMBELAJARAN FISIKA BERBASIS WEB UNTUK MENINGKATKAN ADVERSITY QUOTIENT PESERTA DIDIK," in PROSIDING SEMINAR NASIONAL FISIKA (E-JOURNAL), 2015, vol. 4, pp. SNF2015--II.

[11] I. Amri, S. Syuhendri, and W. Ketang, "Pengembangan Media Pembelajaran E-Learning Berbasis Web untuk mata Kuliah Pendahuluan Fisika Inti," J. Inov. dan Pembelajaran Fis., vol. 2, no. 1, pp. 25-35, 2015.

[12] S. Kalatting, V. Serevina, and I. M. Astra, "Pengembangan Media Pembelajaran Fisika Berbasis Web Menggunakan Pendekatan Guided Discovery Learning," JPPPF (Jurnal Penelit. dan Pengemb. Pendidik. Fis., vol. 1, no. 1, pp. 1-8, 2015.

[13] S. N. Alfath and others, "Pengembangan Media Blended Learning Berbasis Web Enhanced Course Pada Mata Kuliah Fisika Dasar 2 Jurusan Fisika UNNES," UPEJ Unnes Phys. Educ. J., vol. 2, no. 1, 2013.

[14] H. V. Sari and H. Suswanto, "Pengembangan Media Pembelajaran Berbasis Web untuk Mengukur Hasil Belajar Siswa pada Mata Pelajaran Komputer Jaringan Dasar Program Keahlian Teknik Komputer dan Jaringan," J. Pendidik. Teor. Penelitian, dan Pengemb., vol. 2, no. 7, pp. 1008-1016, 2017.

[15] B. Hariadi, M. J. D. Sunarto, and P. Sudarmaningtyas, "Development of web-based learning application for generation Z," Int. J. Eval. Res. Educ., vol. 5, no. 1, pp. 60-68, 2016.

[16] D. L. Saraswati et al., "Development of web-based and e-learning media for physics learning materials in senior high school: a pilot study," J. Phys. Conf. Ser., vol. 1114, p. 012025, Nov. 2018.

[17] N. Demirci, "Developing web-oriented homework system to assess students introductory physics course performance and compare to paper-based peer homework," Turkish Online J. Distance Educ., vol. 7, no. 3, 2006.

[18] M. R. S. Damanik and A. Nurman, "PEMANFAATAN BLOG PADA MATA KULIAH SISTEM INFORMASI GEOGRAFI JURUSAN PENDIDIKAN GEOGRAFI FAKULTAS ILMU SOSIAL UNIVERSITAS NEGERI MEDAN,” J. Geogr., vol. 8, no. 1, 2016.

[19] Y. Zhang and S. Chu, "New Ideas on the Design of the Web-Based Learning System Oriented to Problem Solving From the Perspective of Question Chain and Learning Community," Int. Rev. Res. Open Distrib. Learn., vol. 17, no. 3, 2016.

[20] H. Atan, F. Sulaiman, and R. M. Idrus, "The Effectiveness of Problem-Based Learning in the Web-Based Environment for the Delivery of an Undergraduate Physics Course.," Int. Educ. J., vol. 6, no. 3, pp. 430-437, 2005.

[21] M. D. Gall, W. R. Borg, and J. P. Gall, Educational research: An introduction, 6th ed. 1996. 